\title{
The Positive Influence of Arbuscular Mycorrhizal Fungi on Wheat Growth and Physiology under Drought Conditions
}

\author{
Ilkay Yavas ${ }^{1 *}$, Yelda Emek ${ }^{2}$ \\ 1* Aydin Adnan Menderes University, Kocarli Vocational School, Department of Plant and Animal Production, Aydin, Turkey, (ORCID: 0000-0002-6863-9631), \\ iyavas@adu.edu.tr \\ ${ }^{2}$ Aydin Adnan Menderes University, Faculty of Agriculture, Department of Agricultural Biotechnology, Aydin, Turkey, (ORCID: 0000-0003-1095-3908), \\ yelda@adu.edu.tr
}

(First received 29 September 2021 and in final form 20 December 2021)

(DOI: 10.31590/ejosat.1002430)

ATIF/REFERENCE: Yavas, I. \& Emek, Y. (2021). The Positive Influence of Arbuscular Mycorrhizal Fungi on Wheat Growth and Physiology under Drought Conditions. European Journal of Science and Technology, (31), 409-419.

\begin{abstract}
Drought is one of the most important environmental stresses threatening wheat yield in the world. With global climate change, it is predicted that the precipitation regime will change and dry periods will increase. The use of arbuscular mycorrhizal fungi (AMF) increases drought tolerance in wheat, affecting the physiological and biochemical properties of the plant and may increase yield. An experiment was conducted to examine the effects of nine different AMF, Glomus intraradices, Glomus aggregatum, Glomus mosseage, Glomus clarum, Glomus monosporus, Glomus deserticola, Glomus brasilianum, Glomus tunicatum, Gigaspora margarita on growth and physiology of wheat (Triticum aestivum L.) subjected to different water statues. The seeds were sown in pots containing peat were placed in field. When the results of the study were evaluated, all traits were significantly affected by AMF application in dry conditions, except the leaf area. The highest values of plant height, root length, shoot and root dry weight were obtained by application of T3+AMF4. Shoot fresh weight, SPAD and relative water content reached the highest values under control conditions with the highest water $(200 \mathrm{ml})$. The Fv / Fm value gave better results in pots at T4+AMF1. Root fresh weight and leaf area also increased with increasing water dose, and application of AMF to both seed and root gave the best results. The highest lipid peroxidation level in leaves was obtained from T1 + AMF4 application. In addition, it was observed that the proline and flavonoid content in both leaves and roots increased with AMF application in arid conditions.
\end{abstract}

Keywords: Arbuscular mycorrhizal fungi, Wheat, Fv / Fm, Chlorophyll, Drought, Stomata.

\section{Arbusküler Mikorizal Fungusların Kurak Koşullarda Buğdayın Büyümesi ve Fizyolojisine Olumlu Etkisi}

$\ddot{O} \mathbf{z}$

Kuraklık, dünyada buğday verimini tehdit eden en önemli çevresel streslerden biridir. Küresel iklim değişikliği ile yağış rejiminin değişeceği ve kurak dönemlerin artacağı öngörülmektedir. Arbusküler mikorizal fungusların (AMF) kullanımı, buğdayda kuraklık toleransını artırarak bitkinin fizyolojik ve biyokimyasal özelliklerini etkilemekte ve verimi artırmaktadır. Farklı su dozlarına maruz bırakılan buğday (Triticum aestivum L.) bitkilerinin büyümesi ve fizyolojisi üzerine Glomus intraradices, Glomus aggregatum, Glomus mosseage, Glomus clarum, Glomus monosporus, Glomus deserticola, Glomus brasilianum, Glomus tunicatum ve Gigaspora margarita dokuz farklı AMF'nin etkilerini incelemek için çalışma yürütülmüştür. Torf içeren saksılara ekilen tohumlar tarlaya yerleştirilmiştir. Çalışmanın sonuçları değerlendirildiğinde, kuru koşullarda AMF uygulamasından yaprak alanı hariç tüm özellikler önemli ölçüde etkilenmiş̧ir. Bitki boyu, kök uzunluğu, sürgün ve kök kuru ağırlığının en yüksek değerleri T3+AMF4 uygulaması ile elde edilmiştir. Sürgün taze ağırlık, SPAD ve bağıl su içeriği, en yüksek su $(200 \mathrm{ml})$ ile kontrol koşullarında en yüksek değerlere ulaşmıştır. Fv / Fm değeri T4+AMF1'de potalarda daha iyi sonuç vermiştir. Artan su dozu ile kök taze ağırlığı ve yaprak alanı da artmış ve hem tohuma hem de köke AMF uygulaması en iyi sonuçları vermiştir. Yapraklarda en yüksek lipid peroksidasyon düzeyi T1+AMF4 uygulamasından elde edilmiştir. Ayrıca kurak koşullarda AMF uygulaması ile hem yapraklarda hem de köklerde prolin ve flavonoid içeriğinin arttığı gözlenmiştir.

Anahtar Kelimeler: Arbusküler mikorizal fungus, Buğday, Fv / Fm, Klorofil, Kuraklık, Stoma.

* Corresponding Author: iyavas@ adu.edu.tr 


\section{Introduction}

\subsection{Drought}

Plants are frequently exposed to different environmental stresses that negatively influence growth, development and yield. Drought stress in the world is one of the most important constraints of plant growth and productivity (Al-Karaki et al., 2004). With the increase in climate change, it is expected that the arid areas will increase even more. In the last 35 years, there has been a $40 \%$ decrease in corn and a $21 \%$ decrease in wheat due to drought worldwide (Daryanto et al., 2016).

Drought stress affects plant life in many ways, such as creating a lack of water in the roots, reducing the transpiration rate, and causing oxidative stress (Impa et al., 2012; Hasanuzzaman et al., 2013). Drought stress also causes detrimental effects on plant growth by affecting enzyme activity, ion uptake and nutrient assimilation (Ahanger and Agarwal, 2017; Ahanger et al., 2017).

Drought stress damages the electron transport system in photosynthesis and causes oxidative stress. In addition, it has negative effects on mineral uptake and osmotic adjustment as a result of dehydration in plants. Therefore, it is necessary to improve the drought tolerance of plants in order to increase plant growth and survival in arid and semi-arid regions (Tuo et al., 2017).

The main effect of drought on plant development is related to the permeability of the membranes and the change in active transport and the restriction of water and nutrient intake due to a decrease in the transpiration rate. As a result of the decrease in water content in the soil, stomata are closed in plants and photosynthesis decreases (Pavithra and Yapa, 2018). In many semi-arid regions of the world, inefficient phosphorus content in soils limit plant yield.

Mycorrhizal relationship with plant roots not only increases growth and nutrient uptake but also provides more drought resistance by causing more effective phosphorus uptake in phosphorus-deficient soils (Al-Karaki and Al-Raddad, 1997).

Drought causes a decrease in transpiration rate, stomatal conductivity and an increase in the abscisic acid ratio (ABA). The rate of photosynthesis is negatively affected by the closure of the stomata, membrane damage, especially the enzymes involved in ATP synthesis. Acting as major osmoprotectants, proline, glycine betaine, fructans, trealose, and polyols accumulate at high levels to maintain cell turgor pressure and normal physiological activities (Duc, 2017).

In case of lack of water, the stomata close with the reduction of $\mathrm{CO}_{2}$ intake. Severe drought stress affects plant physiology and growth, causing significant losses in yield and decreasing quality (Posta and Duc, 2020).

\subsection{Arbuscular Mycorrhizal Fungus (AMF)}

Mycorrhiza is the name given to a group of soil fungi called arbuscular mycorrhizal fungi (AMF) that live in common with the roots of some plants. AMF takes carbohydrates from the host plant, while the plant provides more water and mineral substances through the symbiotic relationship. Mycorrhizal association increases the plant nutrients, water content, plant growth and reproductive capacity and also increases the resistance of the plant against environmental problems (Abdelmoneim et al., 2014; Duc, 2017).

The symbiotic relationship between AMF and the roots of higher plants is quite common in nature. Some ecophysiological studies show that AMF association in arid conditions is an important factor in coping with stress (Rapparini and Peñuelas, 2014).

Arbuscular mycorrhizal fungi are in symbiotic relationship with the roots of $80 \%$ of terrestrial plant species and are the most common fungi in the soil. It constitutes $5-36 \%$ of total soil biomass and $9-55 \%$ of soil microorganism biomass (Olsson et al., 1999).

Drought reduces grain yield, tillering, leaf growth, transpiration, photosynthesis, water and nutrient intake. AMF association against environmental stress factors increases the water and nutrient content of the host plant. AMF allows plants to retain their water content by closing their stomata. Osmotic regulation leads to significant changes in plant physiology such as gas exchange $\left(\mathrm{CO}_{2} \leftrightharpoons \mathrm{O}_{2}\right)$, photosynthesis and leaf relative water content. AMF improves the harmful effects of drought stress by preventing the overproduction of ROS (Fouad et al., 2014; Huang et al., 2017).

Most of the studies on the effect of AMFs on plants under arid conditions indicate that it increases the performance of plants. However, the studies conducted are on the effect of drought in the short term (7-14) before harvest (Neumann and George, 2009). AMF positively affected drought tolerance in tomatoes by increasing water use efficiency in arid conditions. Under severe water stress (-1.3 MPa) AMF application to tomato significantly reduced ABA levels in roots and leaves. This is because plants that do not apply AMF are exposed to more intense drought stress and produce more ABA (Chitarra et al., 2016).

Geochelone gigantea promotes the growth of some plants such as corn, soybean, carrot and grape by living symbiotic life with plant roots and plays an important ecological role by contributing significantly to plant nutrition (Olawuyi et al., 2014).

The symbiotic relationship between AMF and plants is one of the adaptations that plants develop in coping with water stress by enhancing their drought response and plant water relations. In addition, AMF also reduces groundwater pollution by reducing the use of chemical fertilizers and removing contaminants from soil and irrigation water (Porcel and Ruiz-Lozano, 2004; Olawuyi et al., 2014; Sharma et al., 2017; Pavithra and Yapa, 2018).

Water deficiency is an important abiotic stress factor that increasingly limits plant growth and yield due to climate change (Aliasgharzad et al., 2006; Sharma et al., 2017). Previous studies (Allen, 1982; Hardie, 1985) highlight the possible roles of AMFs in water uptake and transport to the host plant.

Corn treated with AMF showed higher drought tolerance and better plant growth (Olawuyi et al., 2014). It is observed that barley treated with vesicular arbuscular mycorrhizal fungi (VAM) cause high root colonization 60 days after planting. In addition, it is revealed that there is $59 \%$ root inoculation in VAM plants 60-78 days after planting. VAM association protects the host plants against the harmful effects of drought. The application of mycorrhizal fungi in drought stress conditions 
increases the leaf water content and reduces the negative effects of drought stress (Budak et al., 2017).

Mycorrhizal inoculation with Funneliformis mosseae and Pyrodictium occultum significantly increased drought tolerance of maple through improvement in proline, soluble protein, flavonoid and nutrient intake. Seven weeks after the drought application, root colonization with $F$. mosseae and $P$. occultum decreased significantly. Higher root, shoot and total biomass production was observed in the grafted plants. AMF application in arid conditions caused significant accumulation of proline. AMF also significantly increased the growth and drought tolerance of Trifolium repens with better nutrient absorption and accumulation of soluble protein, proline and flavonoids (Tuo et al., 2017). AMF increased the growth, yield and drought tolerance of soybean plant under drought stress (Pavithra and Yapa, 2018).

Poplars inoculated with AMF grow better in drought stress conditions due to their higher $\mathrm{Chl}$ content, Chl fluorescence parameters and gas exchange capacity (Liu et al., 2015). In soybean exposed to drought, shoot biomass increased, whereas in plants inoculated with AMF, leaf water content, root and shoot proline content increased (Porcel and Ruiz-Lozano, 2004). Mycorrhizal fungi and potassium application improve chlorophyll content, membrane stability, phosphotase activity and leaf protein content in black lentil (Sharma et al., 2017). In areas with limited water, the association of AMF positively affected corn growth. This beneficial effect of AMF is associated with lower lipid peroxidation, higher PSII activity and membrane stability (Quiroga et al., 2017).

Arbuscular mycorrhizal fungi increase the performance of the olive under drought conditions. AMF provides this by increasing water absorption and nutrient uptake, as well as antioxidant enzyme activities responsible for ROS removal (Fouad et al., 2014). Symbiosis with AMF significantly increases nutrient intake of cowpea under drought stress, but does not affect water intake, plant growth, and photosynthesis (Neumann and George, 2009).

AMF application to rice in arid conditions positively affected chlorophyll fluorescence and Fv/Fm value (RuizSánchez et al., 2011). Inoculation with AMF was also effective in increasing production in arid conditions. Colonization of roots by AMF increases the productivity of plants under drought stress (Al-Karaki et al., 2004). The association of plants with AMF not only increases the growth of plants, but also provides mineral element uptake and drought resistance (Ruiz-Lozano et al., 1995). This study reveals that the adverse effects of drought conditions on wheat morphology, physiology and biochemical properties are alleviated by AMF application.

\section{Material and Method}

\subsection{Experimental Details and Treatments}

This study was carried out using Negev wheat (Triticum aestivum $\mathrm{L}$.) variety in plastic pots with a capacity of $4.5 \mathrm{~L}(18.5$ $\mathrm{cm} \times 17.0 \mathrm{~cm}$ ) in Aydin Adnan Menderes University, Koçarlı Vocational School research and application areas. Before placing peat in pots, all pots were washed with $0.1 \% \mathrm{HCl}$ and then washed with pure water and the peat was placed. There are two factors in the experiment as drought and AMF applications. Detailed information about these applications can be found in Table 1.

Table 1. Drought and AMF Applications

\begin{tabular}{ll}
\hline Drought Applications & AMF Applications \\
\hline T1 $-50 \mathrm{ml}$ water & A1 - Control (No AMF application) \\
T2 $-100 \mathrm{ml}$ water & A2 - AMF application to root only \\
T3 $-150 \mathrm{ml}$ water & A3 - AMF application to seed only \\
T4 $-200 \mathrm{ml}$ water & A4 - AMF application both seed and root
\end{tabular}

For AMF 3 and AMF 4 applications, a total of 64 pots were planted with AMF coated seeds. For this, moistened seeds are covered with AMF with the help of natural glue, and then laid in a layer about $3 \mathrm{~cm}$ below the seed bed within 2 hours and covered with peat again. For AMF 2 and AMF 4 applications, AMF suspensions diluted at the recommended level were applied to the roots after emergence. AMF1, on the other hand, was evaluated as a control group that was not applied. At first 10-15 seeds were placed in each pot, but dilution was carried out in the period with 2-3 leaves. Before planting, $200 \mathrm{mg}$ of 15-1515 fertilizer per $\mathrm{kg}$ of dry soil was applied to the pots. In the experiment, seeds were sowed in each pot, then the surface of the pots was irrigated slightly (Yücel et al., 2009).

Commercial preparation containing nine different species of arbuscular mycorrhizal fungi (Glomus intraradices, $G$. aggregatum, G. clarum, G. monosporus, G. deserticola, $G$. brasilianum, G. etunicatum, G. mosseage, Gigaspora margarita), Endo Roots Soluble (ERS) (Biogobal Ltd.) were used.

The experiment was carried out in 128 pots with 4 replications according to the "Completely Randomized Design" with 2 factors. Eight weeks later, the plants were harvested at Zadoks development period 33 (Zadoks et al., 1974).

With the help of ProCheck Decagon Devices, soil humidifier, moisture levels were determined and irrigation was completed.

During the 21 days, all plants were watered daily with 100 $\mathrm{ml}$ of water. Applications were initiated 3 weeks after sowing to assess drought tolerance and sensitivity levels. After the twenty one days, $50 \mathrm{ml}, 100 \mathrm{ml}, 150 \mathrm{ml}$ and $200 \mathrm{ml}$ of water applications were carried out. No herbicides were used. Weed control was carried out manually. 


\subsection{Plant Analysis and Masurements}

Eight weeks after the drought application, the plants were harvested, root and shoot fresh weights were determined. Root and shoot samples were stored in separate plastic bags at $4{ }^{\circ} \mathrm{C}$ until observations were made within 24 hours.

Plant height $(\mathbf{c m})$ : The plant heights were measured 8 weeks after the application of drought stress and stated in $\mathrm{cm}$.

Root length (cm): The root lengths were measured 8 weeks after the application of drought stress and stated in $\mathrm{cm}$.

Relative water content: Three leaf samples were taken from the middle parts of the leaves from the plants selected at the end of the eighth week, and their wet weights were measured. These leaves were kept in distiled water in petri dishes for 6 hours to become turgor and their turgor weights were measured. Dry weight was determined after drying in the oven at $70{ }^{\circ} \mathrm{C}$ for 72 hours. The relative water content of leaf samples of each group was calculated in \% according to the formula below (Barr and Weatherley, 1962);

$$
\mathrm{RWC}(\%)=[(\mathrm{WW}-\mathrm{DW}) /(\mathrm{TW}-\mathrm{DW})] \times 100
$$

RWC $=$ Relative Water Content; WW = Wet Weight; DW = Dry Weight; TW = Turgor Weight

SPAD value: Measured with SPAD 502 device after application of drought stress.

Shoot fresh weight (SFW) (g): The weight of 10 seedlings of shoots was recorded and stated in $\mathrm{g}$.

Shoot dry weight (SDW) (g): The weight of 10 seedlings shoots was recorded and oven drying at $75^{\circ} \mathrm{C}$ at $48 \mathrm{~h}$.

Root fresh weight (RFW) (g): The weight of 10 seedlings of roots was recorded and stated in $\mathrm{g}$.

Root dry weight (RDW) (g): The weight of 10 seedlings of roots was recorded and oven drying at $75^{\circ} \mathrm{C}$ at $48 \mathrm{~h}$.

Photosynthetic yield (chlorophyll fluorescence) (Fv/Fm): Measurements were carried out in 4 replications before harvest. Firstly, the upper surfaces of the middle parts of the leaves were covered for 30 minutes. Variable fluorescence / Maximum fluorescence induction $(\mathrm{Fv} / \mathrm{Fm})$ ratio was determined with the aid of Hansatech Pocket Pea Chlorophyll Fluorimeter.

Leaf area $\left(\mathbf{c m}^{2}\right)$ : It was measured 8 weeks after the application of drought stress.

Proline content in the leaf: At the end of eight weeks, the amount of proline in the leaves was determined by taking samples from the middle parts of the leaves and using the ninhydrin method determined by Bates et al. (1973) at $520 \mathrm{~nm}$ spectrophotometrically with two replicates. Leaf samples were weighed at $0.5 \mathrm{~g}$, then frozen quickly with liquid nitrogen and stored under cold conditions. The amount of proline was determined on the standard chart as $\mathrm{mg}_{\mathrm{gFW}} \mathrm{gF}^{-1}$.

Proline content in root: At the end of eight weeks, the amount of proline in the root was measured using the ninhydrin method of Bates et al. (1973) at $520 \mathrm{~nm}$ spectrophotometrically in two replicates. After the harvested roots were washed and cleared from the soil, they were weighed at $0.25 \mathrm{~g}$, quickly frozen with liquid nitrogen and stored under cold conditions. The amount of proline was determined on the standard chart as $\mathrm{mg} . \mathrm{gFW}^{-1}$.
Flavonoid content in root: Total flavonoid content in the root was determined spectrophometrically at $510 \mathrm{~nm}$ according to Dewanto et al. (2002), which was based on aluminum trichloride method, with two replications. It was determined using $0.1 \mathrm{~g}$ of root from post-harvest shade-dried plants. The plant material was sieved after being powdered with a grinder. Results were calculated in quercetin equivalents using the quercetin calibration curve. It is reported by taking the average of the results.

Flavonoid content in the leaf: Total flavonoid content in the leaf was determined to be two replicates at $510 \mathrm{~nm}$ spectrophometrically according to Dewanto et al. (2002) based on aluminum trichloride method. To determine the flavonoid content, $0.5 \mathrm{~g}$ of shade dried leaves were used. The plant was powdered with a material grinder and then sieved. Results were calculated in quercetin equivalents using the quercetin calibration curve. It is reported by taking the average of the results.

Lipid peroxidation level in leaves: Determination of lipid peroxidation level is based on the spectrophotometric determination of malondialdehyde (MDA), which occurs as a result of oxidative damage, by using thiobarbituric acid (TBA) reagent. The resulting MDA was determined spectrophotometrically using the method developed by Cakmak and Horst (1991), which is based on the formation of a colored complex with TBA. The spectrophotometric absorbances of the samples were determined at $532 \mathrm{~nm}$ and $600 \mathrm{~nm}$. Malondialdehyde concentration (as $\mu \mathrm{M}$ ) was calculated using the extinction coefficient $\left(155 \mathrm{mM}^{-1} \mathrm{~cm}^{-1}\right)$.

\subsection{Statistical analysis}

All the data were statistically analyzed with analysis of variance (ANOVA) procedures using the SPSS software (SPSS Inc., 1999).

The differences between the means were compared by the least significant difference by employing the LSD Test $(p \leq 005)$. Regarding the proline, flavonoid and lipid peroxidation amounts, the averages of the data obtained were calculated using the SPSS 16.0 program. Differences were tested with one-way analysis of variance (ANOVA) and compared with Duncan Multiple Ratio Test at 0.05 significance level.

\section{Results and Discussions}

\subsection{Plant Morphological Properties}

Plant height and root length: The highest plant heights were obtained from T4+AMF3 $(80.01 \mathrm{~cm})$, T3+AMF3 (78.02 $\mathrm{cm})$, T4+AMF4 $(76.01 \mathrm{~cm})$ and T3+AMF4 $(73.89 \mathrm{~cm})$ applications, respectively. This result shows that the AMF application method may change depending on the drought. The lowest data $(52.05 \mathrm{~cm})$ was obtained from pots not treated with $\mathrm{AMF}$ at $50 \mathrm{ml}$ water conditions. Maximum root length values were obtained from $150 \mathrm{ml}$ water application. This was followed by T4, T2 and T1 water applications, respectively. The shortest root length was obtained from pots without AMF under low water conditions. Among the AMF applications, the highest value was observed in the AMF3 application at different water amounts. T1 and T2 water doses and AMF2 showed similar results (Table 2). 
Table 2. Effect of AMF on plant height and root length of wheat plants grown different water concentrations

\begin{tabular}{|c|c|c|c|}
\hline $\begin{array}{c}\text { AMF } \\
\text { Treatment }\end{array}$ & $\begin{array}{c}\text { Water } \\
\text { Treatment }\end{array}$ & $\begin{array}{c}\text { Plant } \\
\text { Height } \\
\text { (cm) }\end{array}$ & $\begin{array}{l}\text { Root Length } \\
(\mathrm{cm})\end{array}$ \\
\hline \multirow{4}{*}{ AMF1 } & T1 & $52.05 \mathrm{dD}$ & $9.93 \mathrm{dD}$ \\
\hline & $\mathbf{T 2}$ & $55.12 \mathrm{dC}$ & $10.93 \mathrm{dC}$ \\
\hline & T3 & $58.10 \mathrm{~dB}$ & $12.48 \mathrm{~dB}$ \\
\hline & T4 & $61.96 \mathrm{dA}$ & $12.72 \mathrm{dA}$ \\
\hline \multirow{4}{*}{ AMF2 } & T1 & $59.14 \mathrm{cD}$ & $12.93 \mathrm{cC}$ \\
\hline & $\mathbf{T} 2$ & $61.02 \mathrm{cC}$ & $13.11 \mathrm{cC}$ \\
\hline & T3 & $64.77 \mathrm{cB}$ & $15.93 \mathrm{cB}$ \\
\hline & T4 & $69.97 \mathrm{cA}$ & $16.37 \mathrm{cA}$ \\
\hline \multirow{4}{*}{ AMF3 } & T1 & $66.87 \mathrm{aD}$ & $16.75 \mathrm{aD}$ \\
\hline & $\mathbf{T 2}$ & $69.16 \mathrm{aC}$ & $17.68 \mathrm{aC}$ \\
\hline & T3 & $78.02 \mathrm{aB}$ & $18.96 \mathrm{aB}$ \\
\hline & T4 & $80.01 \mathrm{aA}$ & $20.17 \mathrm{aA}$ \\
\hline \multirow{4}{*}{ AMF4 } & T1 & $66.03 \mathrm{bD}$ & $15.80 \mathrm{bD}$ \\
\hline & $\mathbf{T 2}$ & $68.09 \mathrm{bC}$ & $16.49 \mathrm{bC}$ \\
\hline & T3 & $73.89 \mathrm{bA}$ & $17.74 \mathrm{bB}$ \\
\hline & T4 & $76.01 \mathrm{bB}$ & $18.86 \mathrm{bA}$ \\
\hline \multicolumn{2}{|c|}{ Water treatment $(\mathrm{A})$} & $* *$ & $* *$ \\
\hline \multicolumn{2}{|c|}{ AMF treatment $(\mathrm{B})$} & $* *$ & $* *$ \\
\hline \multicolumn{2}{|c|}{ Water treatment $\mathrm{x}$ AMF $(\mathrm{AxB})$} & $* *$ & $* *$ \\
\hline & & LSD & LSD \\
\hline & & (AxB): 0.45 & $(\mathrm{AxB}): 0.21$ \\
\hline
\end{tabular}

The sources of variance were as follows: four water treatments, four AMF applications and interaction between water treatment and AMF. Different lower case letters in the same line indicate that the difference between AMF under water treatments and different capital letters indicate that the difference between water doses are significant. Least significant difference (LSD) of the Water Treatment $\mathrm{x}$ AMF interaction **, significant at $1 \%$ levels of probability.

This is in agreement with a study showing that when the effects of eight AMF species (Gigaspora margarita, Funneliformis mosseae, Rhizophagus irregulare, G. clarum, G. deserticola, G. monosporum, G. brasilianum, G. aggregatum) on wheat and legume plants are examined, root biomass, root length, $\mathrm{P}, \mathrm{Fe}$ and $\mathrm{Zn}$ intake has a positive effect on wheat, but the same effect is not observed in legumes (Ingraffia et al., 2019). In addition, in another study, Glomus mosseae application to maize under drought conditions positively affected root weight, plant height, stem length, root length, plant fresh weight, shoot dry weight, root/shoot ratio, chlorophyll content, soluble protein, phosphorus has been reported (Abdelmoneim et al., 2014). The drought tolerant durum wheat genotype showed more mycorrhizal colonization under arid conditions than the drought sensitive genotype. Inoculation with AMF increased total root length and dry matter yield in plants. Although the roots of the drought-resistant genotype were more infected, the droughtsensitive genotype benefited more from AMF infection (AlKaraki and Raddad, 1997). Inoculation with AMF is more important for plant growth in dry conditions than in wet conditions (Michelsen and Rosendahl, 1990). Mycorrhizal colonization with AMF is more in aqueous plants than in arid conditions. Therefore, inoculation with AMF in arid conditions increased the growth, nutrient intake and yield of wheat plants (Al-Karaki et al., 2004).

Leaf area: In dry conditions the highest value was obtained from T4 application and the lowest value was obtained from T1 application. In AMF3 application leaf area gave the highest value (Table 3).

Table 3. Effect of AMF on leaf area of wheat plants grown different water concentrations

\begin{tabular}{|c|c|c|c|c|}
\hline \multirow{6}{*}{$\begin{array}{l}\text { Leaf Area } \\
\qquad\left(\mathrm{cm}^{2}\right)\end{array}$} & \multicolumn{4}{|c|}{ Water Treatment } \\
\hline & T1 & T2 & T3 & T4 \\
\hline & $19.37 \mathrm{a}$ & $23.09 \mathrm{a}$ & $22.47 \mathrm{a}$ & $33.47 \mathrm{a}$ \\
\hline & \multicolumn{4}{|c|}{ AMF } \\
\hline & AMF1 & AMF2 & AMF3 & AMF4 \\
\hline & $17.25 \mathrm{~b}$ & $19.96 \mathrm{ab}$ & $39.24 \mathrm{a}$ & $\begin{array}{c}21.95 \\
\mathrm{ab}\end{array}$ \\
\hline \multicolumn{2}{|c|}{ Water treatment $(\mathrm{A})$} & \multicolumn{2}{|c|}{ ns; $\operatorname{LSD}_{(\mathrm{A})}: 24.61$} & \\
\hline \multicolumn{2}{|c|}{ AMF treatment $(\mathrm{B})$} & \multicolumn{2}{|c|}{ ns; $\operatorname{LSD}_{(\mathrm{B})}: 21.96$} & \\
\hline \multicolumn{2}{|c|}{$\begin{array}{c}\text { Water x AMF treatment } \\
\qquad(\mathrm{AxB})\end{array}$} & \multicolumn{2}{|c|}{ ns } & \\
\hline
\end{tabular}

The sources of variance were as follows: four water treatments, four AMF applications and interaction between water treatment and AMF. Different lower case letters in the same line indicate that the difference between AMF under water treatments are not significant. Least significant difference (LSD) of the Water Treatment x AMF interaction ns, not significant.

Unlike our results, it was determined that leaf area, nitrogen, phosphorus, potassium and calcium contents increased in tomatoes inoculated with AMF. Similarly, application of Glomus deserticola to Antirrhinum majus L. in drought conditions increased shoot and root diameter, shoot length, leaf area, number of leaves per plant, water content, chlorophyll and proline content (Asrar et al., 2012).

\subsection{Yield Related Parameters}

Shoot fresh and dry weight and root dry weight: Table 4 data showed that the highest shoot dry weight was obtained from T4+AMF3 application. This was followed by T3+AMF3 application with $10.13 \mathrm{~g}$. At the lowest water dose the lowest shoot dry weight values were obtained from AMF2 application. In terms of root dry weight it was determined that water and AMF application significantly affected root dry weight. The highest root dry weight $(0.98 \mathrm{~g})$ was obtained from T4 + AMF3 application. This was followed by the T4+AMF4 application. The lowest value $(0.630 \mathrm{~g})$ was obtained from $\mathrm{T} 1+\mathrm{AMF} 1$ pots.

Similarly, under drought stress conditions, after the plants' association with AMF, the proline content in the leaf, photosynthesis, leaf area index, relative growth rate, fresh and dry weight of seeds increased (Pavitra and Yapa, 2018). Pedranzani et al. (2016) emphasized that inoculation of Digitaria eriantha with Rhizophagus irregularis increased shoot dry weight, stomatal conductivity, lipid peroxidation, and $\mathrm{H}_{2} \mathrm{O}_{2}$ content in shoots and roots. Treatment of maize with Rhizophagus intraradices under arid conditions increased the $\mathrm{N}$, $\mathrm{P}, \mathrm{K}$ and $\mathrm{Mg}$ uptake in shoots and plant dry weight (Zhao et al., 2015). Inoculation of Pelargonium graveolens (Amiri et al., 2015) and Robinia pseudoacacia L. (Yang et al., 2014) with Rhizophagus intraradices and Funneliformis mosseae has been observed to increase biomass, water use efficiency and net 
photosynthesis rate. Bernardo et al. (2019) stated that inoculation of Triticum aestivum and Triticum durum with Funneliformis mosseae under arid conditions significantly improved biomass in plants, increased water use efficiency, and reduced oxidative damage. Treatment of lettuce and tomato plants Rhizophagus irregularis, Glomus intraradices in arid conditions increased biomass production, photosystem II activity, ABA accumulation and synthesis, and strigolactone production has been reported (Ruiz-Lozano et al., 2015).

Boyer et al. (2014) reported that treatment of Fragaria ananassa plants with $F$. mosseae BEG25 and $F$. geosporus BEG11 in arid conditions increased shoot and root fresh weight and water use efficiency.

Table 4. Effect of AMF on shoot fresh and dry weight, root dry weight of wheat plants grown different water concentrations

\begin{tabular}{|c|c|c|c|c|}
\hline $\begin{array}{c}\text { AMF } \\
\text { Treatment }\end{array}$ & $\begin{array}{c}\text { Water } \\
\text { Treatment }\end{array}$ & $\begin{array}{c}\text { Shoot } \\
\text { Fresh } \\
\text { Weight } \\
\text { (g) }\end{array}$ & $\begin{array}{c}\text { Shoot } \\
\text { Dry } \\
\text { Weight } \\
\text { (g) }\end{array}$ & $\begin{array}{c}\text { Root } \\
\text { Dry } \\
\text { Weight } \\
\text { (g) }\end{array}$ \\
\hline \multirow{4}{*}{ AMF1 } & T1 & $10.35 \mathrm{~dB}$ & $7.23 \mathrm{cC}$ & $0.63 \mathrm{bD}$ \\
\hline & $\mathbf{T 2}$ & $10.40 \mathrm{~dB}$ & $7.63 \mathrm{bB}$ & $0.70 \mathrm{bC}$ \\
\hline & T3 & $11.14 \mathrm{dA}$ & $8.18 \mathrm{cA}$ & $0.74 \mathrm{cB}$ \\
\hline & T4 & $11.18 \mathrm{dA}$ & $8.37 \mathrm{dA}$ & $0.80 \mathrm{cA}$ \\
\hline \multirow{4}{*}{ AMF2 } & T1 & $11.19 \mathrm{cB}$ & $7.63 \mathrm{bD}$ & $0.68 \mathrm{aD}$ \\
\hline & $\mathbf{T 2}$ & $11.20 \mathrm{cB}$ & $7.89 \mathrm{aC}$ & $0.73 \mathrm{abC}$ \\
\hline & T3 & $13.82 \mathrm{cA}$ & $9.16 \mathrm{bB}$ & $0.78 \mathrm{bB}$ \\
\hline & $\mathbf{T 4}$ & $14.00 \mathrm{cA}$ & $9.77 \mathrm{cA}$ & $0.86 \mathrm{bA}$ \\
\hline \multirow{4}{*}{ AMF3 } & T1 & $12.99 \mathrm{bC}$ & $7.94 \mathrm{aC}$ & $0.68 \mathrm{aD}$ \\
\hline & $\mathbf{T 2}$ & $12.87 \mathrm{bC}$ & $8.10 \mathrm{aC}$ & $0.75 \mathrm{aC}$ \\
\hline & T3 & $15.13 \mathrm{bB}$ & $10.13 \mathrm{aB}$ & $0.88 \mathrm{aB}$ \\
\hline & T4 & $15.85 \mathrm{bA}$ & $10.62 \mathrm{aA}$ & $0.98 \mathrm{aA}$ \\
\hline \multirow{4}{*}{ AMF4 } & T1 & $14.03 \mathrm{aD}$ & $8.01 \mathrm{aB}$ & $0.65 \mathrm{abD}$ \\
\hline & $\mathbf{T} 2$ & $14.65 \mathrm{aC}$ & $8.02 \mathrm{aC}$ & $0.70 \mathrm{bC}$ \\
\hline & T3 & $16.01 \mathrm{aB}$ & $10.05 \mathrm{aA}$ & $0.86 \mathrm{aB}$ \\
\hline & T4 & $16.49 \mathrm{aA}$ & $10.03 \mathrm{aA}$ & $0.96 \mathrm{aA}$ \\
\hline \multicolumn{2}{|c|}{ Water treatment (A) } & $* *$ & $* *$ & $* *$ \\
\hline \multicolumn{2}{|c|}{ AMF treatment (B) } & $* *$ & $* *$ & $* *$ \\
\hline \multicolumn{2}{|c|}{$\begin{array}{l}\text { Water treatment } \times \mathrm{AMF} \\
\qquad(\mathrm{AxB})\end{array}$} & $* *$ & $* *$ & $* *$ \\
\hline & & $\begin{array}{l}\mathrm{LSD}_{(\mathrm{AxB})} \\
\quad 0.31\end{array}$ & $\begin{array}{l}\mathrm{LSD}_{(\mathrm{AxB})}: \\
0.22\end{array}$ & $\begin{array}{l}\mathrm{LSD}_{(\mathrm{AxB})} \\
0.03\end{array}$ \\
\hline
\end{tabular}

The sources of variance were as follows: four water treatments, four AMF applications and interaction between water treatment and AMF. Different lower case letters in the same line indicate that the difference between AMF under water treatments and different capital letters indicate that the difference between water doses are significant. Least significant difference (LSD) of the Water Treatment $\mathrm{x}$ AMF interaction **, significant at $1 \%$ levels of probability.

Root fresh weight: When Table 5 is examined the highest root fresh weight was obtained in T4 conditions, while the lowest value was observed in T1 application. Among the AMF applications, AMF3 gave the best root fresh weight, while similar results were obtained in the AMF4 application.
Table 5. Effect of AMF on root fresh weight of wheat plants grown different water concentrations

\begin{tabular}{lcccc}
\hline & \multicolumn{4}{c}{ Water Treatment } \\
\cline { 2 - 5 } Root & T1 & T2 & T3 & T4 \\
Weight $(g)$ & $1.18 \mathrm{~d}$ & $1.25 \mathrm{c}$ & $1.38 \mathrm{~b}$ & $1.48 \mathrm{a}$ \\
\cline { 2 - 5 } & \multicolumn{5}{c}{ AMF } \\
\cline { 2 - 5 } & AMF1 & AMF2 & AMF3 & AMF4 \\
& $1.21 \mathrm{c}$ & $1.28 \mathrm{~b}$ & $1.50 \mathrm{a}$ & $1.30 \mathrm{~b}$ \\
\hline
\end{tabular}

Water treatment $\quad \mathrm{ns} ; \operatorname{LSD}_{(\mathrm{A})}: 0.027$
(A)

AMF treatment

ns; $\operatorname{LSD}_{(\mathrm{B})}: 0.029$

Water $\mathrm{x}$ AMF

treatment $(\mathrm{AxB})$

ns

The sources of variance were as follows: four water treatments, four AMF applications and interaction between water treatment and AMF. Different lower case letters in the same line indicate that the difference between water treatments and AMF are significant, respectively. Least significant difference (LSD) of the Water Treatment and AMF **, significant at $1 \%$ levels of probability

Our results in Table 5 are consistent with the fact that under arid conditions Glomus fasciculatum, Glomus intraradices and Glomus mosseae fungi significantly affect leaf fresh weight, root fresh and dry weight of the seedless white currant grape cultivar (Aslanpour et al., 2019). According to Metwally et al. (2019), the fresh and dry weights of mycorrhizal plants increased significantly than non-mycorrhizal plants. Behrooz et al. (2019) suggest that AMF improve walnut fresh weight. Previous report indicated that drought stress reduced the total fresh weight in barley, but this reduction occurred by a lesser extent in fungal treatments (Funneliformis mosseae and Rhizophagus irregularis) (Ehsan Mahdavi et al., 2018).

\subsection{Plant Physiological Properties}

SPAD and Relative Water Content: As the water dose increased, the SPAD value increased in wheat (Table 6). At T1 and T2 water doses, AMF2 application gave similar results. The highest SPAD value was obtained from the plants treated with T4+AMF4, followed by T3+AMF4. Results of studies on drought stress showed that plant biomass, chlorophyll content and transpiration rate were higher in plants inoculated with AMF than in control conditions.

The application of different amounts of water and AMF significantly affected the relative water content. It was observed that the application of AMF4 to wheat affected the relative water content positively, and this effect was more pronounced especially in T3 and T4 water applications. In the low water application, the highest value was obtained from the AMF3 application (Table 6).

Likewise, under water deficiency conditions, the association of wheat with Glomus mosseae increased osmotic potential, chlorophyll content, antioxidant enzyme activity, N, P and $\mathrm{K}$ content (Rani, 2016). The symbiotic relationship with AMF delayed leaf aging in alfalfa under drought conditions (Abdelmoneim et al., 2014). Similar results were reported by Pal and Pandey (2016) that plants treated with Glomus mosseae, Glomus fasciculatum and Gigaspora decipiens under drought 
stress increased growth parameters and total chlorophyll content. Under water stress conditions, the combination of arbuscular mycorrhizal fungus Glomus claroideum and wheat increased the total dry weight, relative moisture content and leaf chlorophyll content (Beltrano and Ronco, 2008). Mathur and Vyas (2000) emphasized that arbuscular mycorrhizal root colonization increases the amount of photosynthesis and chlorophyll synthesis associated with plant growth.

Table 6. Effect of AMF on SPAD and relative water content of wheat plants grown different water concentrations

\begin{tabular}{|c|c|c|c|}
\hline $\begin{array}{c}\text { AMF } \\
\text { Treatment }\end{array}$ & $\begin{array}{c}\text { Water } \\
\text { Treatment }\end{array}$ & SPAD & $\begin{array}{c}\text { Relative } \\
\text { Water } \\
\text { Content }(\%)\end{array}$ \\
\hline \multirow{4}{*}{ AMF1 } & T1 & $19.01 \mathrm{cC}$ & $65.00 \mathrm{dD}$ \\
\hline & $\mathbf{T} 2$ & $29.73 \mathrm{cC}$ & $66.00 \mathrm{dC}$ \\
\hline & T3 & $29.86 \mathrm{cB}$ & $68.00 \mathrm{cB}$ \\
\hline & T4 & $30.78 \mathrm{dA}$ & $70.00 \mathrm{dA}$ \\
\hline \multirow{4}{*}{ AMF2 } & T1 & $19.86 \mathrm{bD}$ & $73.67 \mathrm{bD}$ \\
\hline & $\mathbf{T 2}$ & $30.03 \mathrm{cC}$ & $75.00 \mathrm{cC}$ \\
\hline & T3 & $21.19 \mathrm{~dB}$ & $77.00 \mathrm{bB}$ \\
\hline & T4 & $32.17 \mathrm{cA}$ & $78.00 \mathrm{cA}$ \\
\hline \multirow{4}{*}{ AMF3 } & T1 & $20.94 \mathrm{aD}$ & $90.00 \mathrm{aD}$ \\
\hline & $\mathbf{T} 2$ & $36.70 \mathrm{aC}$ & $93.67 \mathrm{aC}$ \\
\hline & T3 & $37.67 \mathrm{bB}$ & $95.00 \mathrm{aB}$ \\
\hline & T4 & $38.08 \mathrm{bA}$ & $96.00 \mathrm{bA}$ \\
\hline \multirow{4}{*}{ AMF4 } & T1 & $20.99 \mathrm{aD}$ & $70.00 \mathrm{cD}$ \\
\hline & $\mathbf{T} 2$ & $35.66 \mathrm{bC}$ & $90.00 \mathrm{bC}$ \\
\hline & T3 & $39.00 \mathrm{aB}$ & $95.00 \mathrm{aB}$ \\
\hline & T4 & $40.93 \mathrm{aA}$ & $97.00 \mathrm{aA}$ \\
\hline \multicolumn{2}{|c|}{ Water treatment $(\mathrm{A})$} & $* *$ & $* *$ \\
\hline \multicolumn{2}{|c|}{ AMF treatment (B) } & $* *$ & $* *$ \\
\hline \multirow{2}{*}{\multicolumn{2}{|c|}{ Water treatment $\mathrm{x}$ AMF $(\mathrm{AxB})$}} & $* *$ & $* *$ \\
\hline & & $\begin{array}{c}\text { LSD } \\
(\mathrm{AxB}): 0.45 \\
\end{array}$ & $\begin{array}{c}\text { LSD } \\
(\mathrm{AxB}): 0.21\end{array}$ \\
\hline
\end{tabular}

The sources of variance were as follows: four water treatments, four AMF applications and interaction between water treatment and AMF. Different lower case letters in the same line indicate that the difference between AMF under water treatments and different capital letters indicate that the difference between water doses are significant. Least significant difference (LSD) of the Water Treatment $\mathrm{x}$ AMF interaction **, significant at $1 \%$ levels of probability

The most important of these is that the symbiotic relationship with AMF increases drought tolerance (Augé, 2001; Ruiz-Lozano, 2003). Application of mycorrhizal fungus to Borago officinalis plant reduces the negative effects of drought stress by increasing the leaf water content (Budak et al., 2017). Earlier studies also suggest that the relationship of roots with AMF increases the drought resistance of wheat (Al-Karaki and Clark, 1998). Sánchez-Blanco et al. (2004) found that the decrease in water content in mycorrhizal relationships was lower under arid conditions.

A study conducted with Anthyllis cytisoides in arid conditions showed that mycorrhizal inoculation does not cause a change in relative water content (Goicoechea et al., 2005).
Drought is one of the important abiotic stresses affecting the growth, development and yield of plants. In dry conditions, there is a decrease in wilting, photosynthesis, stomatal conductivity, water use efficiency and relative water content in plants. In addition, it adversely affects the electron transport system, causing active oxygen formation and stomata closure, which causes a decrease in $\mathrm{CO}_{2}$ uptake. As a result, due to ROS production, photosynthesis is adversely affected and secondary metobilites (isoprenoids, phenols or alkaloids) are synthesized (Ganugi et al., 2019). Bacillus sp., Klebsiella sp., Acinetobacter sp. and arbuscular mycorrhizal fungus Rhizophagus intraradices showed the ability to adapt to physiological parameters (relative water content and stomatal conductivity), increased photosynthetic pigments (chlorophyll and carotenoids) and improved antioxidant enzyme levels (catalase, ascorbate peroxidase, and glutathione reductase tolerance) (Durán et al., 2016). Therefore, it is evident that the mycorrhizal fungal association offers a number of benefits to the plants.

Fv/Fm: When water applications were evaluated, the highest $\mathrm{Fv} / \mathrm{Fm}$ values were obtained from $\mathrm{T} 4$ and $\mathrm{T} 3$ applications, respectively. Among the AMF treatments, the lowest value was obtained under the control conditions, and the highest value was obtained from the pots treated with AMF4 (Table 7).

Table 7. Effect of AMF on Fv/Fm of wheat plants grown different water concentrations

\begin{tabular}{|c|c|c|c|c|}
\hline \multirow{6}{*}{ Fv/Fm } & \multicolumn{4}{|c|}{ Water treatment } \\
\hline & T1 & T2 & T3 & T4 \\
\hline & $0.66 \mathrm{~d}$ & $0.68 \mathrm{c}$ & $0.72 \mathrm{~b}$ & $0.75 \mathrm{a}$ \\
\hline & \multicolumn{4}{|c|}{ AMF } \\
\hline & AMF1 & AMF2 & AMF3 & AMF4 \\
\hline & $0.62 \mathrm{~d}$ & $0.66 \mathrm{c}$ & $0.75 \mathrm{~b}$ & $0.79 \mathrm{a}$ \\
\hline \multicolumn{2}{|c|}{ Water treatment $(\mathrm{A})$} & \multicolumn{3}{|c|}{ ns; LSD $_{(\mathrm{A})}: 0.026$} \\
\hline \multicolumn{2}{|c|}{ AMF treatment (B) } & \multicolumn{3}{|c|}{$\mathrm{ns} ; \operatorname{LSD}_{(\mathrm{B})}: 0.018$} \\
\hline
\end{tabular}

Water $\mathrm{x}$ AMF treatment $(\mathrm{AxB})$

ns

The sources of variance were as follows: four water treatments, four AMF applications and interaction between water treatment and AMF. Different lower case letters in the same line indicate that the difference between water treatments and AMF are significant, respectively. Least significant difference (LSD) of the Water Treatment and AMF **, significant at $1 \%$ levels of probability.

Proline content: As the water dose increased, the amount of proline in the wheat leaves decreased. In terms of the amount of proline in the leaf, the highest value was obtained from T1+AMF4 application. This was followed by plants treated with T2+AMF4. The lowest value was obtained from T4+AMF1 application. As can be understood from these results, the amount of proline in the leaves increased with AMF application. In AMF1 application, the lowest value was determined in T4 and the highest value was determined in T1 application (Table 8).

With the drought, there is a $44 \%$ increase in the total proline level. In AMF applications, the highest values were obtained in 
AMF4 + T1 application. When the amount of proline in AMF1 + $\mathrm{T} 1$ application and the amount of proline in AMF4 $+\mathrm{T} 1$ application are compared, it is seen that there is an $86.6 \%$ increase in AMF4 + T1 application. These results show us that a significant increase in the amount of proline is achieved with AMF applications. When the results obtained in terms of root proline content are examined, it is seen that the highest proline amount $\left(7.20 \mathrm{mg} \mathrm{gFW}^{-1}\right)$ was obtained at $\mathrm{T} 1+\mathrm{AMF} 1$ application. In AMF1 applications, the lowest amount of proline was obtained in T4 application. Proline value in wheat increased by $165.68 \%$ in AMF1 application at low water dose compared to high dose. There was an increase in the amount of proline with drought. Similar to leaves, proline increased in roots with AMF application. However, higher concentrations of proline were observed in lower water concentration treatments such as $\mathrm{T} 1$ and T2 compared to leaves.

Table 8. Average values for proline amounts in leaves and roots

\begin{tabular}{ccccccccc}
\hline AMF & \multicolumn{1}{c}{ Leaf Proline $\left(\mathrm{mg} . \mathrm{g} \mathrm{FW}^{-1}\right)$} & \multicolumn{4}{c}{ Root Proline $\left(\mathrm{mg.gFW}{ }^{-1}\right)$} \\
\hline & T1 & T2 & T3 & T4 & T1 & T2 & T3 & T4 \\
\hline AMF1 & 3.60 & 2.62 & 2.36 & 2.01 & 7.20 & 5.25 & 3.22 & 2.71 \\
& $\mathrm{a}$ & $\mathrm{ab}$ & $\mathrm{b}$ & $\mathrm{b}$ & $\mathrm{a}$ & $\mathrm{b}$ & $\mathrm{c}$ & $\mathrm{c}$ \\
\hline AMF2 & 4.60 & 4.25 & 3.51 & 2.07 & 5.22 & 4.60 & 3.46 & 2.72 \\
& $\mathrm{a}$ & $\mathrm{ab}$ & $\mathrm{b}$ & $\mathrm{c}$ & $\mathrm{a}$ & $\mathrm{a}$ & $\mathrm{a}$ & $\mathrm{a}$ \\
\hline AMF3 & 5.19 & 4.52 & 4.10 & 3.59 & 5.49 & 4.75 & 4.10 & 3.59 \\
& $\mathrm{a}$ & $\mathrm{a}$ & $\mathrm{a}$ & $\mathrm{a}$ & $\mathrm{a}$ & $\mathrm{ab}$ & $\mathrm{ab}$ & $\mathrm{b}$ \\
\hline AMF4 & 6.72 & 5.70 & 4.52 & 4.47 & 6.10 & 4.96 & 4.20 & 4.00 \\
& $\mathrm{a}$ & $\mathrm{ab}$ & $\mathrm{b}$ & $\mathrm{b}$ & $\mathrm{ab}$ & $\mathrm{a}$ & $\mathrm{a}$ & $\mathrm{a}$ \\
\hline
\end{tabular}

Differences were compared by Duncan Multiple Ratio Test. The same lower case letters indicate that the difference between AMF applications at different water doses is not significant ( $\mathrm{P}$ $<0.05)$.

It was reported by Pavitra and Yapa (2018) that the proline content in the leaf increased after the plants were associated with AMF under drought stress conditions. Zhu et al. (2011), in dry conditions have observed high proline content after mycorrhizal fungal application to the Zea mays. They also found that drought increased the proline level in the root. Tuo et al. (2017) emphasized that mycorrhizal inoculation in the Trifolium plant increased the level of proline. In addition, these researchers have been observed that the AMF has increased the growth of Trifolium repens, drought tolerance, nutrient absorption, soluble protein, proline and flavonoid content, and prevent drought tolerance. Pavithra and Yapa (2018) has been emphasized that Glycine $\max \mathrm{L}$ are inoculated with $\mathrm{AMF}$ in water stress conditions has a higher proline level. In addition, Begum et al. (2019) emphasized that the Zea mays plant increases the prolin level in the plants exposed to the AMF application, both moderate and severe drought.

Flavonoid content: The research results showed that there is a negative relationship between the water dose and the amount of flavonoids. Among the AMF1 applications, the flavonoid amount in T1 which is the lowest water dose has a higher value than other water concentrations (Table 9). Due to drought flavonoid content increased in both roots and leaves. An increase is also seen in all water applications, where AMF is applied. Flavonoids increased in roots and leaves with AMF application. At T4 water concentration flavonoid accumulation in roots and leaves is lower than other concentrations. Inoculation with AMF did not show a significant increase in flavonoid value in highly irrigated T3 and T4 plants. However, in AMF1 application when T4 irrigation application was compared with T1 irrigation application it was determined that there was an increase of $160 \%$. Likewise, in AMF4 application, when T1 irrigation application is compared with T4 irrigation application, an increase of $407 \%$ is observed. This result shows us that the increase in flavonoids in high water dose is less than in low water applications.

Table 9. Average values of flavonoids in leaves and roots

\begin{tabular}{ccccccccc}
\hline AMF & \multicolumn{3}{c}{$\begin{array}{c}\text { Leaf Flavonoid } \\
\left(\mathrm{mg.g} \mathrm{DW}^{-1}\right)\end{array}$} & \multicolumn{4}{c}{$\begin{array}{c}\text { Root Flavonoid } \\
\left(\mathrm{mg.g} \mathrm{DW}^{-1}\right)\end{array}$} \\
\hline & T1 & T2 & T3 & T4 & T1 & T2 & T3 & T4 \\
\hline AMF1 & 13.0 & 9.0 & 5.0 & 2.4 & 8.1 & 4.0 & 2.8 & 2.6 \\
& $\mathrm{a}$ & $\mathrm{b}$ & $\mathrm{c}$ & $\mathrm{c}$ & $\mathrm{a}$ & $\mathrm{b}$ & $\mathrm{b}$ & $\mathrm{b}$ \\
\hline AMF2 & 16.2 & 11.0 & 7.0 & 3.3 & 9.3 & 7.4 & 3.2 & 3.0 \\
& $\mathrm{a}$ & $\mathrm{b}$ & $\mathrm{c}$ & $\mathrm{d}$ & $\mathrm{a}$ & $\mathrm{a}$ & $\mathrm{b}$ & $\mathrm{b}$ \\
\hline AMF3 & 16.6 & 14.2 & 9.2 & 3.4 & 8.9 & 7.0 & 3.2 & 3.3 \\
& $\mathrm{a}$ & $\mathrm{ab}$ & $\mathrm{bc}$ & $\mathrm{c}$ & $\mathrm{a}$ & $\mathrm{b}$ & $\mathrm{c}$ & $\mathrm{c}$ \\
\hline AMF4 & 20.3 & 16.0 & 9.8 & 4.0 & 12.4 & 10.0 & 6.3 & 4.1 \\
& $\mathrm{a}$ & $\mathrm{a}$ & $\mathrm{b}$ & $\mathrm{c}$ & $\mathrm{a}$ & $\mathrm{ab}$ & $\mathrm{bc}$ & $\mathrm{c}$ \\
\hline
\end{tabular}

Differences were compared by Duncan Multiple Ratio Test. The same lower case letters indicate that the difference between AMF applications at different water doses is not significant $(\mathrm{P}$ $<0.05)$.

Similar results to our findings on the effect of water defiency on flavonoid accumulation are found by Abbaspour et al. (2012), Pistachia vera L. also in their work, has been achieved. The researchers investigated the inoculated plants with Glomus etunicatum, well watered and arid conditions. They stated that the flavonoid content of the leaves increased in both applications. Similar results were obtained in a study conducted by Tue et al. (2017).

Flavonoids are the main secondary metabolites found in most vascular plants that can eliminate reactive oxygen species to protect plant species from oxidative damage (Wu et al., 2014). Therefore flavonoids are associated with the entire mechanism that protects cells from oxidative damage, except that they act as filters (Gould et al., 1995). As a result higher flavonoid content means stronger resistance to oxidative stress. The results show that AMF inoculation causes changes in the amount of flavonoids and increases drought resistance.

Lipid peroxidation level in leaves: As a result of the applications, the amount of lipid peroxidation in the leaves is as indicated in Table 10. According to the MDA measurement results, when the amount of lipid peroxidation is examined, the highest value is 1.38 in AMF1 + T1 application. In addition, when AMF 1 applications were evaluated, it was observed that the amount of MDA increased with the increase in drought. In the control group, AMF1+T1, lipid peroxidation increased $115 \%$ compared to AMF1+T4 level. In all AMF applications, there was a decrease in the amount of MDA. In terms of MDA amount, 
approximately $40 \%$ decrease was observed in MDA amount with AMF application in T1 application.

Table 10. Average values for leaf lipid peroxidation content

\begin{tabular}{ccccc}
\hline & \multicolumn{4}{c}{ Lipid peroxidation $(\mu$ mol MDA.g FW $)$} \\
\hline AMF treatment & T1 & T2 & T3 & T4 \\
\hline AMF1 & $1.38 \mathrm{a}$ & $0.81 \mathrm{~b}$ & $0.76 \mathrm{~b}$ & $0.64 \mathrm{~b}$ \\
AMF2 & $0.86 \mathrm{a}$ & $0.75 \mathrm{~b}$ & $0.68 \mathrm{~b}$ & $0.46 \mathrm{c}$ \\
AMF3 & $0.91 \mathrm{a}$ & $0.73 \mathrm{~b}$ & $0.69 \mathrm{c}$ & $0.57 \mathrm{~d}$ \\
AMF4 & $0.82 \mathrm{a}$ & $0.64 \mathrm{~b}$ & $0.50 \mathrm{c}$ & $0.39 \mathrm{~d}$ \\
\hline
\end{tabular}

Similarly our findings on lipid peroxidation, Begum et al. (2019) observed high MDA in maize crops in drought conditions. Pedranzani et al. (2016) emphasized that the inoculation of Digitaria eriantha with Rhizophagus irregularis increases lipid peroxidation in arid conditions.

One of the by-products, MDA, is generally accepted as a reflection of membrane degradation, dysfunction or membrane lipid peroxidation (Lecan and Baccou, 1998; Ali et al., 2005). ROS increase occurs with drought stress. In lipid peroxidation, the increase of reactive oxygen species also causes an increase in the amount of MDA. With AMF application, MDA level decreased and reduced oxidative damage.

\section{Conclusions and Recommendations}

Water causes a significant decrease in crop production in the world, especially in arid and semi-arid regions. Drought, which is one of the most severe abiotic stresses that threatens plant growth and yield, has significantly affected the morphological and physiological characteristics and yield components of wheat. AMF applied at different water doses, especially AMF3 and AMF4, alleviated the negative effects on plant morphology, physiology and yield components. In other words, it can be concluded that the application of AMF significantly reduced the detrimental effects of drought stress on wheat plants grown in arid conditions.

\section{Acknowledge}

We thank the Projects of Scientific Investigation of Aydın Adnan Menderes University for funding (Project number: KOMYO19002).

\section{References}

Abbaspour, H., Saeidi-Sar, S., Afshari, H., Abdel-Wahhab, M. (2012). Tolerance of mycorrhiza infected pistachio (Pistacia vera L.) seedling to drought stress under glasshouse conditions. J. Plant Physiol., 169:704-709.

Abdelmoneim, T.S., Tarek, A., Moussa, A., Almaghrabi, O., Hassan, A., Alzahrani, S., Abdelbagi, I. (2014). Increasing plant tolerance to drought stress by inoculation with arbuscular mycorrhizal fungi. Life Sci J., 1(1): 10-17.

Ahanger, M.A., Agarwal, R.M. (2017). Potassium up-regulates antioxidant metabolism and alleviates growth inhibition under water and osmotic stress in wheat (Triticum aestivum L.). Protoplasma, 254 (4): 1471-1486.

Ahanger, M.A., Tittal, M., Mir, R.A., Agarwal, R.M. (2017). Alleviation of water and osmotic stress-induced changes in nitrogen metabolizing enzymes in Triticum aestivum L. cultivars by potassium. Protoplasma, 254 (5): 1953- 1963.
Ali, M.B., Hahn, E., Paek, K. (2005). Effects of temperature on oxidative stress defense systems, lipid peroxidation and lipoxygenase activity in Phalaenopsis. Plant Physiol Biochem., 43: 213-223.

Aliasgharzad, N., Neyshabouri, M.R., Salimi, G. (2006). Effects of arbuscular mycorrhizal fungi and Bradyrhizobium japonicum on drought stress of soybean. Biologia, 61 (Suppl. 19): 324-328.

Al-Karaki, G.N., Al-Raddad, A. (1997). Effects of arbuscular mycorrhizal fungi and drought stress on growth and nutrient uptake of wheat genotypes differing in drought resistance. Mycorrhiza, 7:83-88.

Al-Karaki, G.N., Clark, R.B. (1998). Growth, mineral acquisition, and water use by mycorrhizal wheat grown under water stress. J Plant Nutr., 21:263-276.

Al-Karaki, G., McMichael, B., Zak, J. (2004). Field response of wheat to arbuscular mycorrhizal fungi and drought stress. Mycorrhiza, 14: 263-269.

Allen, M.F. (1982). Influence of vesicular-arbuscular mycorrhiza on water movement through Buteloua gracilis LAG ex STEUD. New Phytol., 91:191-196.

Amiri, R., Nikbakht, A., Etemadi, N. (2015). Alleviation of drought stress on rose geranium [Pelargonium graveolen (L.) Herit] in terms of antioxidant activity and secondary metabolites by mycorrhizal inoculation. Sci. Hort., 197:373380 .

Aslanpour, M., Baneh, H.D., Tehranifar, A., Shoor, M. (2019). Effect of water stress on growth traits of roots and shoots (fresh and dry weights, and amount of water) of the white seedless grape. International Transaction Journal of Engineering, Management, \& Applied Sciences \& Technologies, 10(2):169-181.

Asrar, A.A., Abdel-Fattah, G.M., Elhindi, K.M. (2012). Improving growth, flower yield, and water relations of snapdragon Antirhinum majus L. plants grown under wellwatered and water-stress conditions using arbuscular mycorrhizal fungi. Photosynthetica, 50: 305-316.

Augé, R.M. (2001). Water relations, drought and vesicular arbuscular mycorrhizal symbiosis. Mycorrhiza, 11: 3-42.

Barr, H.D., Weatherley, P.E. (1962). A re-examination of the relative turgidity techniques for estimating water deficits in leaves. Australian Journal of Biological Sciences, 15: 413428.

Bates, L.S., Waldren, R.P., Teare, I.D. (1973). Rapid determination of free proline for water stress studies. Plant and Soil, 39:205-207.

Begum, N., Ahanger, M.A., Su, Y., Lei, Y., Mustafa, N.S.A., Ahmad, P., Zhang, L. (2019). Improved drought tolerance by AMF inoculation in maize (Zea mays) involves physiological and biochemical implications. Plants, 8:579. doi:10.3390/plants8120579

Behrooz, A., Vahdati, K., Rejali, F., Lotfi, M., Sarikhani, S., Leslie, C. (2019). Arbuscular mycorrhiza and plant growthpromoting bacteria alleviate drought stress in walnut. HortScience, 54:1087-1092.

Beltrano, J., Ronco, M.G. (2008). Improved tolerance of wheat plants (Triticum aestivum L.) to drought stress and rewatering by the arbuscular mycorrhizal fungus Glomus claroideum: effect on growth and cell membrane stability. Brazilian Journal of Plant Physiology, 20(1): 29-37.

Bernardo, L., Carletti, P., Badeck, F.W., Rizza, F., Morcia, C., Ghizzoni, R., Rouphael, Y., Colla, G., Terzi, V., Lucini, L. (2019). Metabolomic responses triggered by arbuscular 
mycorrhiza enhance tolerance to water stress in wheat cultivars. Plant Physiol. Biochem., 137: 203-212.

Boyer, L.R., Brain, P. Xu, X.M., Jeffries, P. (2014). Inoculation of drought-stressed strawberry with a mixed inoculum of two arbuscular mycorrhizal fungi: effects on population dynamics of fungal species in roots and consequential plant tolerance to water. Mycorrhiza, 25 (3): 215-227.

Budak, B., Khavalti, M.A., Özkan, Ş.S. (2017). The usage of native arbuscular mycorrhizal fungi (AMF) in drought areas and low-input crop production systems. ADÜ Ziraat Fak. Derg., 14(2): 69-73.

Cakmak, I., Horst, W.J. (1991). Effect of aluminum on lipid peroxidation, superoxide dismutase, catalase and peroxidase activities in rot tips of soybean (Glycine max). Physiologia Plantarum, 83:463-468.

Chitarra, W., Maserti, B., Gambino, G. Guerrieri, E., Balestrini, R. (2016). Arbuscular mycorrhizal symbiosis-mediated tomato tolerance to drought. Plant Signal Behav., 11: 10091023.

Daryanto, S., Wang, L., Jacinthe, P.A. (2016). Global synthesis of drought effects on maize and wheat production. PLoS One, 11:e0156362. doi: 10.1371/journal. pone.0156362

Dewanto, V., Wu, X., Adom, K.K., Liu, R.H. (2002). Thermal processing enhances the nutritional value of tomatoes by increasing total antioxidant activity. J. Agric. Food Chem., 50: 3010-3014.

Duc, N.H. (2017). Impact of arbuscular mycorrhizal fungi on plant tolerance to some abiotic stresses and phytopathogens. $\mathrm{PhD}$ dissertation. Szent István University. Godollo. $122 \mathrm{p}$.

Durán, P., Acuña, J., Armada, E., López-Castillo, O., Cornejo, P., Mora, M., Azcón, R. (2016). Inoculation with selenobacteria and arbuscular mycorrhizal fungi to enhance selenium content in lettuce plants and improve tolerance against drought stress. J Soil Sci Plant Nutr., 16(1): 211-225.

Ehsan Mahdavi, S.M., Salehi, H., Zarei, M. (2018). Can arbuscular mycorrhizal fungi ameliorate the adverse effects of deficit irrigation on tall fescue (Festuca arundinacea Schreb.)? J Soil Sci Plant Nut., 18: 636-652.

Fouad, M.O., Essahibi, A., Benhiba, L., Qaddoury, A. (2014). Effectiveness of arbuscular mycorrhizal fungi in the protection of olive plants against oxidative stress induced by drought. Span J Agric Res., 12: 763-77.

Ganugi, P., Masoni, A., Pietramellara, G., Benedettelli, S. (2019). A review of studies from the last twenty years on plantarbuscular mycorrhizal fungi associations and their use for wheat crops. Agronomy, 9(12): 840.

Goicoechea, N., Merino, S., Sánchez-Díaz, M. (2005). Arbuscular mycorrhizal fungi can contribute to maintain antioxidant and carbon metabolism in nodules of Anthyllis cytisoides L. subjected to drought. J. Plant Physiol., 162: 2735 .

Gould, K.S., Kuhn, D.N., Lee, DW. (1995). Oberbauer ST. Why leaves are sometimes red. Nature, 378: 241-2.

Hardie, K. (1985). The effect of removal of extraradical hyphae on water uptake by VAM plants. New Phytol., 101: 677-684

Hasanuzzaman, M., Gill, S.S., Fujita, M. (2013). Physiological role of nitric oxide in plants grown under adverse environmental conditions, in plant acclimation to environmental stress. 269-322. Tuteja N and SS Gill (eds). (NY: Springer Science+Business Media). doi: 10.1007/9781-4614-5001-6_11

Huang, Y.M., Zou, Y.N., Wu, Q.S. (2017). Alleviation of drought stress by mycorrhizas is related to increased root
$\mathrm{H}_{2} \mathrm{O}_{2}$ efflux in trifoliate orange. Sci Rep., 7:42335. Available at: http://doi: 10.1038/srep42335 (Accessed: 16 May 2021)

Impa, S.M., Nadaradjan, S., Jagadish, S.V.K. (2012). Drought stress induced reactive oxygen species and anti-oxidants in plants, in Abiotic stress responses in plants: metabolism, productivity and sustainability. 131-147. Ahmad, P., Prasad, M.N.V. (eds). (LLC: Springer Science+ Business Media). doi: 10.1007/978-1-4614-0634-1_7

Ingraffia, R., Amato, G., Frenda, A.S., Giambalvo, D. (2019). Impacts of arbuscular mycorrhizal fungi on nutrient uptake, $\mathrm{N}_{2}$ fixation, $\mathrm{N}$ transfer, and growth in a wheat/faba bean intercropping system. PLoS ONE, 14(3): e0213672

Lacan, D., Baccou, J.C. (1998). High levels of antioxidant enzymes correlate with delayed senescence in nonnetted muskmelon fruits. Planta, 204: 377-382.

Liu, T., Sheng, M., Wang, C.Y., Chen, H., Li, Z., Tang, M. (2015). Impact of arbuscular mycorrhizal fungi on the growth, water status, and photosynthesis of hybrid poplar under drought stress and recovery. Photosynthetica, 53: 250258.

Mathur, N., Vyas, A. (2000). Influence of arbuscular mycorrhizae on biomass production, nutrient uptake and physiological changes in Ziziphus mauritana Lam under water stress. J. Arid Environ., 45:191-195.

Metwally, A., Azooz, M., Nafady, N., El-Enany, A. (2019). Arbuscular mycorrhizal symbiosis alleviates drought stress imposed on wheat plants (Triticum aestivum L.). Applied Ecology and Environmental Research, 17 (6):13713-13727.

Michelsen, A., Rosendahl, S. (1990). The effect of VA mycorrhizal fungi, phosphorus and drought stress on the growth of Acacia nilotica and Leucaena leucocephala seedlings. Plant Soil., 124:7-13.

Neumann, E., George, E. (2009). The effect of arbuscular mycorrhizal root colonization on growth and nutrient uptake of two different cowpea (Vigna unguiculata [L.] Walp.) genotypes exposed to drought stress. Emir J Food Agric., 21:1-17.

Olawuyi, O.J., Odebode, A.C., Babalola, B.J., Afolayan, E.T., Onu, C.P. (2014). Potentials of Arbuscular Mycorrhiza Fungus in Tolerating Drought in Maize (Zea mays L). American Journal of Plant Sciences, 5:779-786.

Olsson, P.A., Thingstrub, I., Jakobsen, I., Baath, E. (1999) Estimation of the biomass of arbuscular mycorrhizal fungi in a linseed field. Soil Biol Biochem., 31:1879-1887

Pal, A., Pandey, S. (2016). Role of arbuscular mycorrhizal fungi on plant growth and reclamation of barren soil with wheat (Triticum aestivum L.) crop. Int J Soil Sci., 12: 25-31.

Pavithra, D., Yapa, N. (2018). Arbuscular mycorrhizal fungi inoculation enhances drought stress tolerance of plants. Groundwater for Sustainable Development, 7: 490-494.

Pedranzani, H., RodrãGuez-Rivera, M., GutiaRrez, M., Porcel, R., Hause, B., Ruiz-Lozano, J.M. (2016). Arbuscular mycorrhizal symbiosis regulates physiology and performance of Digitaria eriantha plants subjected to abiotic stresses by modulating antioxidant and jasmonate levels. Mycorrhiza, 26:141-152.

Porcel, R., Ruiz-Lozano, J.M. (2004). Arbuscular mycorrhizal influence on leaf water potential, solute accumulation and oxidative stress in soybean plants subjected to drought stress. Journal of Experimental Botany, 55:1743-1750.

Posta, K., Duc, N.H. (2020). Benefits of Arbuscular Mycorrhizal Fungi Application to Crop Production under Water Scarcity. Drought Detect Solut Available online: Available at: 
https://www.intechopen.com/books/droughtdetection-andsolutions/benefits-of- arbuscular-mycorrhizal-fungiapplication-to-crop-production-underwater-scarcity (Accessed: 14 May 2021)

Quiroga. G., Erice, G., Aroca, R., Chaumont, F., Ruiz-Lozano, J.M. (2017). Enhanced drought stress tolerance by the arbuscular mycorrhizal symbiosis in a drought-sensitive maize cultivar is related to a broader and differential regulation of host plant aquaporins than in a droughttolerant cultivar. Front Plant Sci., (8):1056. Available at: http://doi: 10.3389/fpls.2017.01056 (Accessed: 16 May 2021)

Rani, B. (2016). Effect of arbuscular mycorrhiza fungi on biochemical parameters in wheat Triticum aestivum L. under drought conditions. Doctoral dissertation, CCSHAU, Hisar.

Rapparini, F., Penuelas, J. (2014). Mycorrhizal fungi to alleviate drought stress on plant growth. In: Use of Microbes for the Alleviation of Soil Stress, 21-42. Miransari M (eds). Springer, New York, NY

Ruiz-Lozano, J.M., Azon, R., Gomez, M. (1995). Effects of arbuscular-mycorrhizal Glomus species on drought tolerance: physiological and nutritional plant responses. Appl Environ Microbiol., 61:456-460.

Ruiz-Lozano, J.M. (2003). Arbuscular mycorrhizal symbiosis and alleviation of osmotic stress. New Perspectives Molecular Stud Mycorrhiza, 13:309-317

Ruiz-Lozano, J.M., Aroca, R., Zamarreño, Á.M., Molina, S., Andreo-Jiménez, B., Porcel, R., García-Mina, J.M., RuyterSpira, C., López-Ráez, J.A. (2015). Arbuscular mycorrhizal symbiosis induces strigolactone biosynthesis under drought and improves drought tolerance in lettuce and tomato. Plant Cell Environ., 39 (2): 441-452. doi: 10.1111/pce.12631

Ruiz-Sánchez, M., Armada, E., Muñoz, Y., de Salamone, I.E.G., Aroca, R., Ruiz-Lozano, J.M., Azcón, R. (2011). Azospirillum and arbuscular mycorrhizal colonization enhanced rice growth and physiological traits under wellwatered and drought conditions. J. Plant Physiol., 168: 1031-1037

Sánchez-Blanco, M.J., Fernández, T., Morales, M.A., Morte, A., Alarcón, J.J. (2004). Variations in water status, gas exchange, and growth in Rosmarinus officinalis plants infected with Glomus deserticola under drought conditions. J. Plant Physiol., 161: 675-682.

Sharma, N., Yadav, K., Aggarwal, A. (2017). Role of potassium and arbuscular mycorrhizal fungi in alleviation of water stress on Vigna mungo. Environmental and Experimental Biology, 15:15-24.

SPSS Inc. (1999) SPSS for Windows: Base 10.0 Applications Guide. Chicago, Illinois

Tuo, X.Q., He, L., Zou, Y.N. (2017). Alleviation of drought stress in white clover after inoculation with arbuscular mycorrhizal fungi. Notulae Botanicae Horti Agrobotanici Cluj-Napoca, 45:220-224

Wu, Q.S., Zou, Y.N., Abd-Allah, E.F. (2014). Mycorrhizal association and ROS in plants. 453-475. In: Ahmad P. (eds.). Oxidative Damage to Plants Antioxidant. Academic Press.

Yang, Y., Tang, M., Sulpice, R., Chen, H., Tian, S., Ban, Y. (2014). Arbuscular mycorrhizal fungi alter fractal dimension characteristics of Robinia pseudoacacia, L. seedlings through regulating plant growth, leaf water status, photosynthesis, and nutrient concentration under drought stress. J Plant Growth Regul., 33:612-625.
Yücel, C., Özkan, H., Ortaş, I., Yağbasanlar, T. (2009). Screening of wild emmer wheat accessions (Triticum turgidum subsp. dicoccoides) for mycorrhizal dependency. Turk J Agric For., 33:513-523.

Zadoks, J.C., Chang, T.T., Konzak, C.F. (1974). A decimal code for the growth stage of cereals. Weed Res., 14:415-421.

Zhao, R., Guo, W., Bi, N., Guo, J., Wang, L., Zhao, J., Zhang, J. (2015). Arbuscular mycorrhizal fungi affect the growth, nutrient uptake and water status of maize (Zea mays, L.) grown in two types of coal mine spoils under drought stress. Appl Soil Ecol., 88:41-49.

Zhu, X., Song, F., Liu, S. (2011). Arbuscular mycorrhiza impacts on drought stress of mazize oplants by lipid peroxidation, proline content and activity of antioxidant system. Journal of Food, Agriculture \& Environment, 9(2):583-587. 